\title{
Lettuce seedlings development index in different substrates using multivariate analysis
}

\section{Índice de desenvolvimento de plântulas de alface em diferentes substratos utilizando análise multivariada}

\author{
André Carlos AULER ${ }^{1}$; Shivelly Los GALETTO ${ }^{2}$; Anderson Rodrigo SILVA ${ }^{3}$; \\ Regina Bellan VERONA ${ }^{4}$ \\ ${ }^{1}$ Autor para correspondência (Corresponding author), Doutorando em Agronomia pela Universidade Estadual de \\ Ponta Grossa; Campus Uvaranas, Av. General Carlos Cavalcanti, 4748, CEP 84030-900, Ponta Grossa, \\ Paraná; aulerac@gmail.com \\ ${ }^{2}$ Doutoranda em Agronomia pela Universidade Estadual de Ponta Grossa; shivelly@gmail.com \\ ${ }^{3}$ Doutorando em Estatística e Experimentação Agronômica pela Escola Superior de Agricultura "Luiz de \\ Queiroz"; ar.silva@usp.br \\ ${ }^{4}$ Especialista em Gestão, Manejo e Nutrição Na Bovinocultura Leiteira pela Universidade do Oeste de Santa \\ Catarina; reginaverona_10@hotmail.com
}

Recebido em:11-04-2014; Aceito em: 20-10-2014

\begin{abstract}
The quality seedlings production, which is dependent on the substrate used, are fundamental to the establishment of vegetable crops. The aim of this study was to evaluate the quality of lettuce seedlings in response to addition of vermiculite concentrations of substrates (pine bark, coconut fiber and peat) through the use of multivariate statistical methods. An experiment was conducted, where treatments consisted of vegetable substrates combinations and three concentrations of vermiculite (0, 25 and $50 \%)$, were added to the substrates. Lettuce crop was used as test plant, from which we evaluated the seedlings emergence, the root volume (RV), roots and shoot fresh and dry phytomass, true leaves number and the smaller true leaf height. The principal component analysis and canonical discriminant function analysis were applied. The seedling emergence was lower when using coconut fiber as substrate. The other variables evaluated have had maximum increments when using peat. The first two principal components explained $84.70 \%$ of the total variance. The RV was the most important for seedlings produced, variable highlighted by the use of the two multivariate methods, which has proved to be suitable for qualitative assessments of seedlings. The quality of lettuce seedlings is not affected by the addition of vermiculite in substrates composed of pine bark, coconut fiber and peat.
\end{abstract}

Additional keywords: coconut fiber; Lactuca sativa L.; peat; pine bark; principal component analysis.

\section{Resumo}

A produção de mudas de qualidade, as quais são dependentes do substrato utilizado, são fundamentais para o estabelecimento das culturas hortícolas. Objetivou-se neste trabalho avaliar a qualidade de mudas de alface em resposta a adição de concentrações de vermiculita em substratos (casca de pinus, fibra de coco e turfa) por meio do uso de métodos estatísticos multivariados. Para tanto, conduziu-se um experimento onde os tratamentos foram às combinações dos substratos hortícolas e três concentrações de vermiculita $(0,25$ e $50 \%)$, adicionadas aos substratos. Utilizou-se como planta teste a cultura da alface, onde se avaliou a emergência de plântulas, o volume de raízes (VR), a fitomassa fresca e seca de raízes e da parte aérea, o número de folhas verdadeiras e a altura da menor folha verdadeira. Foram aplicados dois métodos estatísticos multivariados: a análise de componentes principais e a análise de função discriminante canônica. A emergência de plântulas foi menor quando se utilizou a fibra de coco como substrato. As demais variáveis avaliadas obtiveram máximos incrementos quando se utilizou turfa. Os dois primeiros componentes principais explicaram $84,70 \%$ da variância total. O VR foi a variável mais importante para as mudas produzidas, destacada pelos dois métodos multivariados, que se mostraram adequados para avaliações qualitativas das mudas produzidas. A qualidade de mudas de alface não é afetada pela adição de vermiculita em substratos compostos por casca de pinus, fibra de coco e turfa.

Palavras-chave adicionais: análise de componentes principais; casca de pinus; fibra de coco; Lactuca sativa L.; turfa. 


\section{Introduction}

Lettuce (Lactuca sativa L.) is one of the most cultivated vegetables in Brazil. In lettuce cultivation, as well as in other vegetables, seedling production use is made, which constitutes one of the most important stages of horticultural production, since it acts directly on the plants final performance and in the production process (SILVEIRA et al., 2002).

In recipient seedling production, substrates are used to replace soil. Substrates are a porous medium formed by materials of mineral, organic or synthetic origin, which have wide variation on its properties (FERMINO \& KÄMPF, 2012). The substrate used in seedlings production is essential in seedlings germination and establishment, once factors such as structure, aeration, water holding capacity and pathogens contamination degree may vary depending on the material used (FERNANDES et al., 2012).

However, substrates properties are sporadically not satisfactory, being then necessary to use a conditioner to improve the present deficiencies, such as water, aeration and nutrients retention, among others. Among the recommended conditioners, vermiculite is highlighted (ARAÚJO NETO et al., 2009; CARVALHO et al., 2007). The vermiculite is added in mixtures with the intention of further improvements in the substrate physical properties, providing a greater aeration and water retention in less porous substrates (WENDLING \& GATTO, 2002).Thus, vermiculite addition may provide the development of better quality lettuce seedlings.

The use of materials considered as substrates conditioners were studied in several crops, such as lettuce (MENEZES JR et al., 2000; PETTER et al., 2012), tomato (RAMOS et al, 2008), peppers (ARAÚJO NETO et al., 2009), papaya (MESQUITA et al., 2012), gypsophila (BOSA et al., 2003) and Baccharis trimera (CARVALHO et al., 2007).

Multivariate analysis refers to statistical methods that simultaneously analyze multiple variables, where initially all variables are considered equally important. Among multivariate methods, there is the principal component analysis (PCA), a method that enables to examine correlations between variables, identify and eliminate those that do little to the total variance. However, PCA is not a method that allows variables or treatments grouping. In this context, complementary methods to PCA are needed, such as the discriminant function analysis (DFA), which aims to separate two or more groups of individuals based on the differences between individuals Mahalanobis distance (MANLY, 2008).

There are few studies that consider the interrelationships between variables by the use of multivariate statistical methods for data analysis. In this context, the aim of this study was to evaluate, through multivariate statistical methods use, lettuce seedlings quality in response to the addition of different vermiculite concentrations in horticultural substrates (pine bark, coconut fiber and peat).

\section{Material and methods}

The study was conducted in the city of São José do Cedro/SC (26이'36"south latitude, 5330'37" west longitude and $717 \mathrm{~m}$ above sea level elevation), in 2011 from September to October, in a protected environment. The region climate, according to Köppen (Cfa) and Thornthwaite (B2rB'2a') classification, is predominantly mesothermal humid, with hot summers and an average temperature of $17.6^{\circ} \mathrm{C}$.

The experiment was installed in a completely randomized design with four repetitions and nine treatments, arranged in a factorial scheme $(3 \times 3)$. The factors evaluated were: substrates (pine bark, coconut fiber and peat) and vermiculite addition proportions $(0,25$ and $50 \%$ of the substrate total volume). Mixtures happened in a 1:4 ratio to $25 \%$ and in $1: 2$ to $50 \%$ (volume/volume), using a $500 \mathrm{~cm}^{3}$ capacity beaker as meter. After divided, the vermiculite and substrates proportions were manually homogenized in polyethylene trays, for subsequent packing in tranches. Substrates and vermiculite (which were purchased in the local market) physical and chemical characteristics are shown in Table 1.

Two hundred cells polystyrene trays were used, where each plot was composed of 40 cells, with a useful area of 16 central cells. After conditioning the mixtures in trays, the sowing of the iceberg lettuce cv. Grand Rapids TBR proceeded, with a depth of one inch and three seeds per cell. It is emphasized that this cultivar was selected for its use by regional producers.

The irrigation management was based exclusively on the floating system. In this system, the polystyrene trays were continuously suspended on water, without addition of nutritive solution. With daily monitoring, it was found that, in the treatments with coconut fiber, there was no seedling emergence due to the lack of water absorption by the substrate. Then, five days after sowing (DAS), irrigation was performed on all treatments using a hand sprayer. At 12 DAS, cells containing more than one emerged seedling thinning proceeded, and only the biggest seedling in each cell was maintained.

Seedling emergence was evaluated at nine and 12 DAS (\%), with emerged seedlings considered the ones with one centimeter above substrate. At 27 DAS root volume (RV, $\mathrm{cm}^{3}$ plant $\left.^{-1}\right)$, smaller true leaf height (STLH, cm), true leaves number (TLN, dimensionless), roots (RFP e RDP, $g$ plant $^{-1}$ ) and shoot (SFP and SDP, $g$ plant $^{-1}$ ) fresh and dry phytomass from viable seedlings were determined. 
Table 1 - Values referenced in the literature for physical and chemical characteristics of vegetable substrates (pine bark, coconut fiber and peat) and of the conditioner (vermiculite) used in the production of lettuce seedlings.

\begin{tabular}{|c|c|c|c|c|c|c|}
\hline Substrate & $\begin{array}{c}\mathrm{Dd} \\
\left(\mathrm{g} \mathrm{cm}^{-3}\right)\end{array}$ & TP & $\begin{array}{c}A S \\
\left(\mathrm{~cm}^{3} \mathrm{~cm}^{-3}\right)\end{array}$ & AW & RW & $\underset{\left(g^{\mathrm{kg}}{ }^{-1}\right)}{\mathrm{OM}}$ \\
\hline Pine bark & $0.24-0.36$ & 0.76 & 0.13 & 0.30 & 0.31 & 15.9 \\
\hline Coconut fiber & $0.05-0.07$ & 0.96 & $0.18-0.46$ & $0.15-0.20$ & 0.05 & 90.0 \\
\hline Peat & $0.24-0.27$ & 0.78 & $0.15-0.32$ & $0.11-0.27$ & 0.35 & $10.5-47.6$ \\
\hline Vermiculite & 0.10 & 0.79 & 0.31 & 0.08 & 0.40 & 0.2 \\
\hline & $\begin{array}{c}\mathrm{pH}\left(\mathrm{H}_{2} \mathrm{O}\right) \\
1: 1\end{array}$ & \multicolumn{2}{|c|}{----- $\left(\mathrm{mg} \mathrm{dm}^{-3}\right)$----- } & $\mathrm{Ca}$ & $\begin{array}{c}\mathrm{Mg} \\
\mathrm{cmol}_{\mathrm{c}} \mathrm{dm}\end{array}$ & CEC \\
\hline Pine bark & $4.7-6.5$ & $76-317.4$ & $690-800$ & $14.8-19.2$ & $6.7-7.9$ & $30.3-71.2$ \\
\hline Coconut fiber & $4.4-6.4$ & 77.19 & $2.8-38.0$ & 1.81 & 1.13 & 5.11 \\
\hline Peat & $3.8-5.8$ & $14.4-75$ & $108-176$ & $25.9-33.7$ & $4.7-6.2$ & $48.7-83.5$ \\
\hline Vermiculite & 6.7 & 2.2 & 80 & 1.23 & 6.2 & 50.9 \\
\hline
\end{tabular}

Dd - dry density; TP - total porosity; AS - aeration space; AW - available water; RW - residual water; OM - organic matter; $\mathrm{pH}$ - hydrogenionic potential; $\mathrm{P}, \mathrm{K}, \mathrm{Ca}$ e $\mathrm{Mg}$ - available phosphorus, potassium, calcium and magnesium, respectively; CEC cation exchange capacity. Adapted from SCHMITZ et al., (2002), CARRIJO et al., (2002), LOPES et al. (2007), RAMOS et al. (2008), FERMINO \& KÄMPF (2012), PETTER et al. (2012).

After seedlings trays removal, seedlings were immersed in water to remove substrate residues. This procedure was repeated until there were no residues stuck to seedlings. Then, seedlings were placed on paper towel for water excess draining. With the help of a stiletto, seedlings were divided on roots and shoot for further independent evaluations. Embryonic leaves were removed when necessary.

To determine RV, graduated cylinder methodology was used. The procedure consisted in placing roots in a graduated cylinder $(25 \mathrm{~mL}$, in this study) containing a known water volume. Through water volume difference before and after roots addition in the tube, the direct response was obtained through unit equivalence $\left(1 \mathrm{~mL}=1 \mathrm{~cm}^{3}\right)$.

After determining the volume, roots were again deposited on paper towel to remove water excess, then weighed on an analytical balance to obtain RFP and stored in paper envelopes, duly labeled, to determine RDP.

Through shoot TLN was determined by direct counting and, in sequence, STLH was determined in a similar way to that conducted by TRANI et al. (2007), utilizing a graduated scale. After completing these assessments, the shoot was weighed on an analytical balance to determine SFP. Then, samples were stored in paper envelopes, as well as it was made to roots, to determine SDP. RDP and PASF were obtained by drying in an oven at $65^{\circ} \mathrm{C}$ with air circulation for a period of 18 hours, until constant weight was obtained.

Emergency data were subjected to univariate analysis of variance. Residual normality and homoscedasticity presuppositions were checked using Shapiro-Wilk and Levene's tests, respectively. If presuppositions were not met, data angular transformation $[\operatorname{arc} \sin (\sqrt{ } / 100)]$ and $F$ tests were used. When necessary, Tukey's test was used to compare means. All inferential procedures were performed considering a $5 \%$ significance level.

The principal component analysis (PCA) was performed based on the correlation matrix between RV, STLH, TLN, SFP, SDP, RFP and RDP variables and standardized (mean zero and variance one). To complement PCA, aiming a better treatment differentiation, canonical discriminant function analysis (DFA) was applied, considering the nine treatments as grouping factor. The accumulated variance proportion $(\geq 80 \%)$ of the generated variables was used as criteria for principal components and discriminant functions number selection. Statistical analyzes were processed using software $R$, version 3.0.2 (R CORE TEAM, 2013).

\section{Results and discussions}

Substrates provided a great influence in the emergence of lettuce seedlings. The increase in the vermiculite concentration of 25 to $50 \%$ increased lettuce seedlings emergence for coconut fiber treatment, while the isolated use of this substrate provided low emergence at nine DAS (Figure 1A). However, even with vermiculite addition, the performance of seedlings produced in this substrate was lower than in the use of pine bark and peat. The lower seedling emergence with coconut fiber use can be explained by the fact of having no occurred water absorption in these treatments, probably due to increased lignin content of this fiber (CARRIJO et al., 2002). SANTOS et al. (2007) reported that soybean seed varieties with higher lignin content showed a lower water absorption speed. Therefore, as sufficient water availability for seeds soaking was not provided, the germination process was not unleashed, subsequently preventing seedling emergence (TAIZ \& ZEIGER, 2013). 
At 12 DAS in the coconut fiber treatment, the maximum seedling emergence occurred with the addition of $50 \%$ vermiculite. However, it showed no significant difference in relation to $25 \%$ addition (Figure 1B). These results are probably due to the high water absorption and retention capacity that the vermiculite possesses (SCHMITZ et al., 2002). Similar results were obtained by SILVEIRA et al. (2002), who found that in tomato seedling production the isolated coconut fiber all owed a lower germination in relation to the one mixed with conditioners.
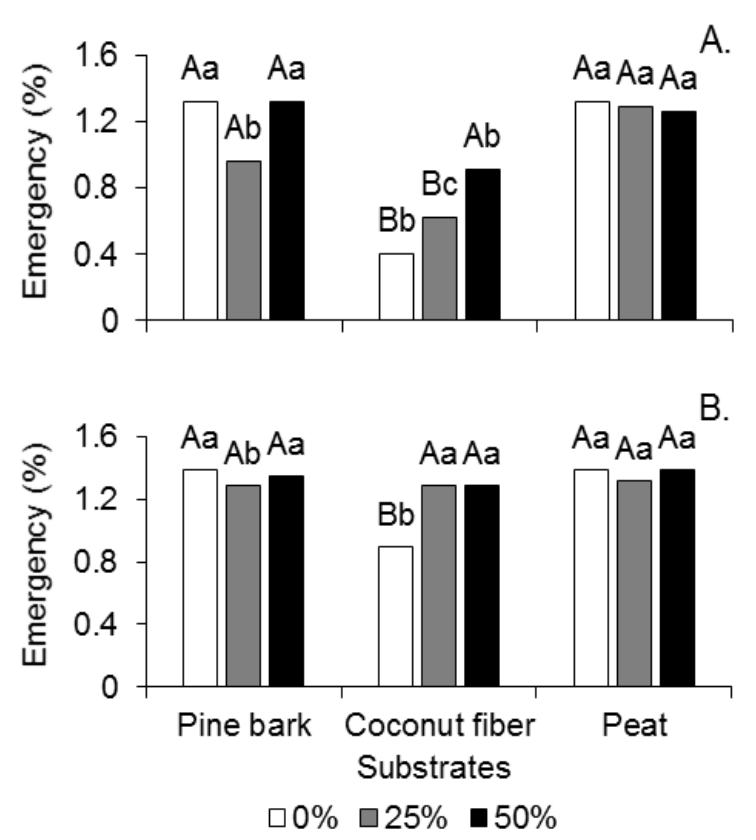

Figure 1 - Emergency (\%) of lettuce seedlings at nine $(A)$ and twelve (B) days after sowing, on different substrates, in response to additions of vermiculite. Means processed [arc sin $(\sqrt{ } y / 100)]$ by the same capital letter for the percentage of vermiculite, followed by the same small letter between the substrates do not differ significantly by Tukey's test $(p \leq 0.05)$.

Peat and pine bark treatments showed similar results among them, both when used alone and in mixture with vermiculite. The only statistically significant difference between peat and pine bark was observed in the addition of $25 \%$ vermiculite at nine DAS (Figure $1 \mathrm{~A}$ ), where peat use gave a higher emergence percentage. The likely explanation for this finding is due to differences in the pine bark granulometry, despite being the same source material and trademark (although from different lots). This highlights the need for norms standardization in commercial substrates production for plant propagation.

In literature, there are studies reporting the granulometric differentiation of substrates from different brands and source materials (SCHMITZ et al., 2002; TRANI et al., 2007).
TRANI et al. (2007) point out that substrates particle size distribution influence on its physical and hydraulic properties, such as water retention, which probably occurred in this work, thus explaining the lower seedling emergence.

The first two principal components (PC) generated explained $84.70 \%$ of the total variation (Figure 2). However, most of the variance is deposited on the PC1 (73.20\%), represented by the set of all variables, except SDP (Table 2). Thus, the PC2 had a small accumulation of variance (11.50\%) and is represented exclusively by SDP, as it had the lowest correlations with other variables.

$\mathrm{RV}$, the variable that presented the highest eigenvector (Table 2) and best correlated with the first principal component, was positively correlated with TLN and STLH (Figure 2), indicating that a good root system development affects the seedling shoot. Marques et al. (2003) found a similar behavior evaluating root length and the number of lettuce leaves at 26 DAS, using a single substrate (mixture of manure, expanded vermiculite and pine bark), but with different recipient volumes for seedlings production. BELLÉ \& KÄMPF (1993) also attributed to the root system (volume, length and surface) the main biometric alterations in yellow passion fruit seedlings, in response to the addition of another conditioner (carbonized rice husk), regardless of peat added volume (33, 50 and $66 \%)$.

Table2 - Eigenvectors, eigenvalues and percentage of variance explained for the first two principal components (PC1 and PC2) biometric variables lettuce seedlings combinations of vegetable substrates and additions of vermiculite.

\begin{tabular}{lcc}
\hline Variable & PC1 & PC2 \\
\hline SFP & 0.93 & -0.26 \\
SDP & 0.60 & 0.76 \\
RFP & 0.85 & -0.28 \\
RDP & 0.93 & -0.23 \\
TLN & 0.84 & 0.08 \\
STLH & 0.85 & 0.12 \\
RV & 0.94 & 0.10 \\
\hline Eigenvalues & 2.26 & 0.90 \\
\hline Variance (\%) & 73.20 & 11.50 \\
\hline
\end{tabular}

SFP - Shoot fresh phytomass; SDP - Shoot dry phytomass; RFP - Root fresh phytomass; RDP - Root dry phytomass; TLN - True leaves number; STLH - Smaller true leaf height; RV - Roots volume.

Looking at Figure 2 it can be seen that two samples showed an intermediate behavior, i.e., a seedling exclusively produced in pine bark may be both from the first or from the second 
region, and the other discordant seedling, produced in peat without vermiculite addition, may be from the second or third region. Also, it was observed that another individual produced exclusively by peat showed a greater RV, TLN,
STLH, RFP, RDP and SFP in relation to other individuals of the third region, so it was not initially entered in this group.

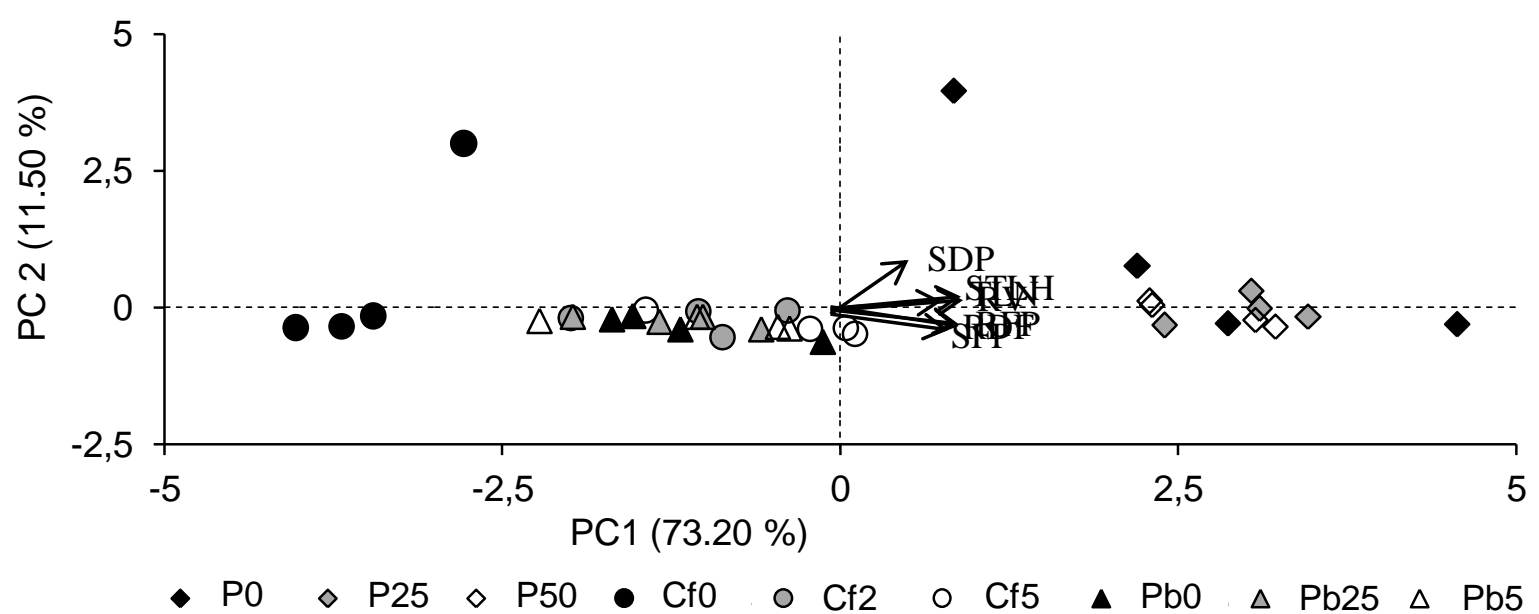

Figure 2 - Biplot for the first two principal components (PC1 and PC2) of biometric variables lettuce seedlings in combinations of substrates and horticultural vermiculite additions. $\mathrm{Pb0}, \mathrm{Pb} 25$ and $\mathrm{Pb} 50-$ pine bark with 0, 25 e 50\% vermiculite, respectively; Cf0, Cf25 and Cf50 - coconut fiber with 0, 25 and $50 \%$ vermiculite, respectively; P0, P25 and P50 - peat with 0, 25 and 50\% vermiculite, respectively.

However, as it is not PCA objective to form groups, a DFA was performed on the first two principal components, aiming to group similar individuals. The first discriminant function (DF) explained almost all of the variance $(97.86 \%)$, being then DF2 was conveniently used, only for a better view of the results (Figure 3 ). As in the $\mathrm{PC} 1$, the RV was the variable that best represented the DF1, followed by RDP and SDP (Table 3), confirming that an adequate seedling root development generates best seedlings.

After finishing the analysis, only two groups were discriminated (Figure 3): G1) the group formed by seedlings with pine bark and coconut fiber in all vermiculite concentrations and with only one exclusively produced with peat; and G2) composed of seedlings produced with peat in all conditioner concentrations.

Table 3 - Linear discriminant coefficients for the first two discriminant functions (DF) of biometric variables lettuce seedlings in combinations of vegetable substrates and additions vermiculite.

\begin{tabular}{ccc}
\hline Variable & DF1 & DF2 \\
\hline SFP & 0.58 & -1.89 \\
SDP & 0.79 & -0.24 \\
RFP & -0.18 & -0.01 \\
RDP & 0.34 & 2.30 \\
TLN & 0.25 & 0.78 \\
STLH & 0.25 & -0.44 \\
RV & -10.24 & -6.66 \\
\hline
\end{tabular}

SFP - Shoot fresh phytomass; SDP - Shoot dry phytomass; RFP - Root fresh phytomass; RDP - Root dry phytomass; TLN - True leaves number; STLH - Smaller true leaf height; $\mathrm{RV}$ - Roots volume.
The seedlings produced under exclusive use of coconut fiber were those that most differed (Figure 3), indicating that this group presented lower RV, TLN, STLH, RFP RDP and SFP. RICKLI et al. (2012) found an increased Pogostemon clabin rooting with vermiculite addition on coconut fiber, giving similar results to those of individual pine bark use when mixed with the conditioner.

The quality increase in coconut fiber produced seedlings caused by vermiculite addition, especially on $50 \%$, may be because seedlings have emerged beforehand (Figure 1A) compared to the exclusive use of the substrate, resulting in higher RV, TLN , STLH, RFP, RDP and SFP due to higher growth period (MENEZES JÚNIOR et al., 2000; RAMOS et al., 2008).

The results for the treatments with pine bark contrasted those obtained by TRANI et al. (2007). In the present study, treatments with pine bark promoted adequate seedling emergence, but the subsequent seedlings development was unsatisfactory. The probable explanation for the lower development was pine bark based substrates physical characteristics (BOSA et al., 2003). As the particles presented an increased size, its arrangement sets a porous space composed of large pores (MENEZES JÚNIOR et al., 2000). Moreover, in the system used in seedling production (floating), which is usually employed by regional producers, the substrate usually tends to be saturated in most of the cultivation, thus presenting aeration deficiency. 


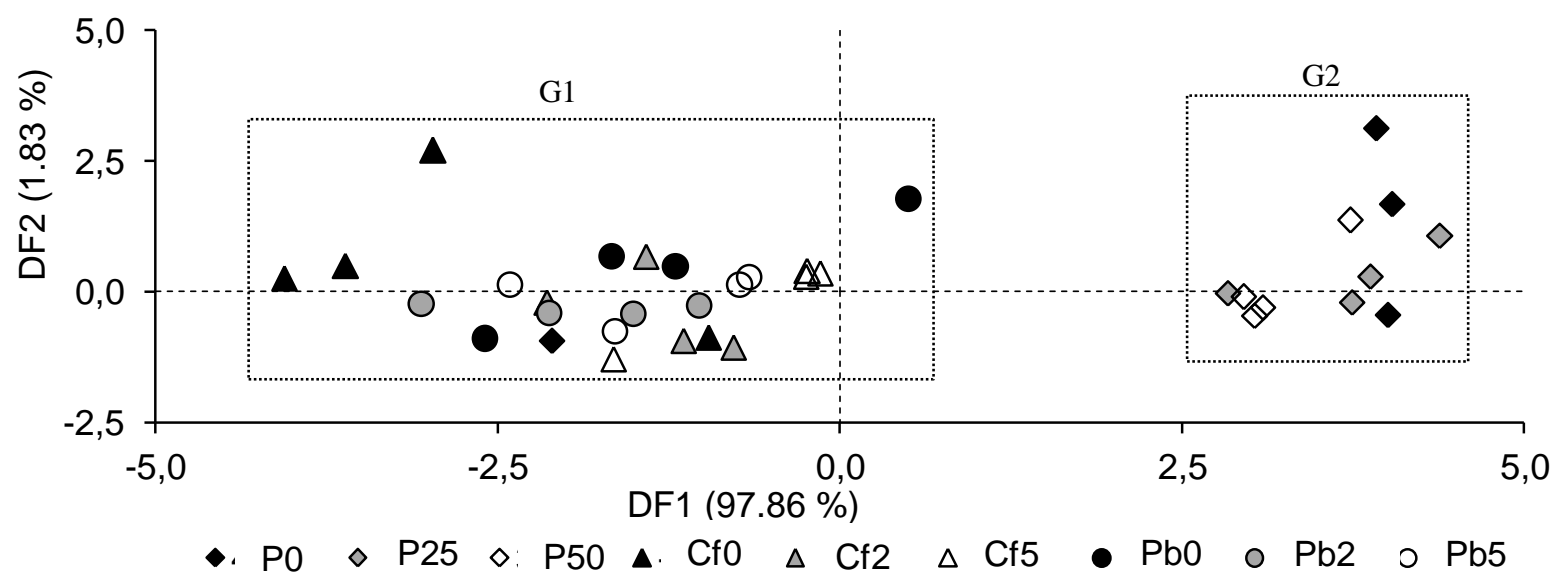

Figure 3 - Biplot for the first two discriminant functions (DF1 and DF2) of biometric variables lettuce seedlings in combinations of substrates and horticultural vermiculite additions. G1 - group 1; $\mathrm{G} 2$ - group 2. $\mathrm{Pb0}, \mathrm{Pb} 25$ and $\mathrm{Pb} 50$ - pine bark with 0,25 e $50 \%$ vermiculite, respectively; $\mathrm{Cf0}$, Cf25 and $\mathrm{Cf} 50$ - coconut fiber with 0,25 and $50 \%$ vermiculite, respectively; P0, P25 and P50- peat with 0 , 25 and $50 \%$ vermiculite, respectively).

The aeration deficiency effects on substrate were mainly reflected in RV, corroborating with findings by BOSA et al. (2003) for different substrates. In an anoxic (completely lacking of oxygen) or hypoxic (partially oxygen-deficient) environment, electron transport and oxidative phosphorylation in mitochondria does not occur, thus Krebs cycle cannot operate and adenosine triphosphate molecules (ATP) begin to be produced by pyruvate fermentation, which shows a low liquid yield compared to aerobic respiration. Thus, as ATP is required in a number of physiological processes, roots damage (which will be reflected in the shoot) are originated by the lack of ATP. It is highlighted that, in saturation conditions, stomatal closure occurs, thereby decreasing water and nutrients absorption, which reduces the accumulation of organic compounds on tissues (TAIZ \& ZEIGER, 2013). Therefore, the lack of ATP and the possible lower nutrients absorption are the factors that best explain SDP reduction for the treatments with pine bark. These results indicate that, for this substrate type, floating irrigation is not indicated.

The second group discriminated by DFA, represented by the lettuce seedlings produced with peat in all vermiculite concentrations, was the one that presented variables highest values (Figure 3). Higher homogeneity between seedlings grown with peat in 25 to $50 \%$ additions compared to the exclusive peat use was obtained.

Explanations for the increase of lettuce seedlings quality provided by peat use in the present study may be related with the increased nutrients availability that this material contains (Table 1), thus favoring seedling growth and development (MENEZES JÚNIOR et al., 2000;
SCHMITZ et al., 2002). An improvement in the substrate physical-chemical properties may also have occurred due to density reduction and increased aeration space and organic matter content (BELLÉ \& KÄMPF, 1993).

With the use of multivariate methods (PCA and DFA) it was possible to analyze the combined behavior of the variables evaluated on the final result of produced seedlings, unlike what happens in univariate statistical analyzes. SILVA et al. (2012), evaluating the effect of copper doses on the growth and quality of Ateleia glazioviana and Lafoensia pacari seedlings, observed that PCA proved to be the most sensitive method to determine copper doses influence on the growth parameters of $A$. glazioviana seedlings under conventional analysis (univariate). DIAS et al., (2007) concluded that the multivariate analysis results in dependent variables better combined information utilization. CASTRO et al. (2013) concluded that multivariate statistic is efficient in assessing wood quality for charcoal production. Thus, the results obtained in this work, together with literature discussions, indicate that multivariate data analysis can provide more clear and precise conclusions for qualitative studies on the production of lettuce seedlings.

\section{Conclusions}

Lettuce seedlings quality is not affected by the addition of vermiculite in substrates composed of pine bark, coconut fiber and peat.

The use of multivariate statistics proved to be adequate for qualitative assessments in the production of lettuce seedlings in response to vermiculite addition in horticultural substrates. 


\section{References}

ARAÚJO NETO, S. E.; AZEVEDO, J. M. A.; GALVÃO, R. O.; OLIVEIRA, E. B. L.; FERREIRA, R. L. F. Produção de muda orgânica de pimentão com diferentes substratos. Ciência Rural, Santa Maria, v.39, n.5, p.1408-1413, 2009.

BELLÉ, S.; KÄMPF, A. N. Produção de mudas de maracujá-amarelo em substratos à base de turfa. Pesquisa Agropecuária Brasileira, Brasília, v.28, n.3, p.385-390, 1993.

BOSA, N.; CALVETE, E. O.; KLEIN, V. A.; SUZIN, M. Crescimento de mudas de gipsofila em diferentes substratos. Horticultura Brasileira, Brasília, v.21, n.3, p.514-519, 2003.

CARRIJO, O. A.; LIZ, R. S.; MAKISHIMA, N. Fibra da casca do coco verde como substrato agrícola. Horticultura Brasileira, Brasília, v.20, n.4, p.533535, 2002.

CARVALHO, R. I. N.; NOLASCO, M. A.; CARVALHO, T.; RIPKA, M.; GIUBLIN, L. M.; NEGRELLO, M.; SCHEFFER, M. C. Enraizamento de estacas de carqueja em função de diferentes substratos e posições do ramo em plantas masculinas e femininas. Scientia Agrária, Curitiba, v.8, n.3, p.269-274, 2007.

CASTRO, A. F. N. M.; CASTRO, R. V. O.; CARNEIRO, A. C. O.; LIMA, J. E. Análise multivariada para seleção de clones de eucalipto destinados à produção de carvão vegetal. Pesquisa Agropecuária Brasileira, Brasília, v.48, n.6, p.627-635, 2013.

DIAS, P. F.; SOUTO, S. M.; FRANCO, A. A. Leguminosas arbóreas introduzidas em pastagem. Pesquisa Agropecuária Brasileira, Brasília, v.42, n.1, p.119-126, 2007.

FERMINO, M. H.; KÄMPF, A.N. Densidade de substratos dependendo dos métodos de análise e níveis de umidade. Horticultura Brasileira, Brasília, v.30, n.1, p.75-79, 2012.

FERNANDES, L. F.; GOMES, W. A.; MENDONÇA, R. M. N. Substratos na produção de porta-enxertos cítricos em ambiente protegido. Revista Verde de Agroecologia e Desenvolvimento Sustentável, Mossoró, v.7, n.3, p.01-06, 2012.

LOPES, J. L. W.; GUERRINI, I. M.; SAAD, J. C. C.; SILVA, M. R. Nutrição mineral de mudas de eucalipto produzidas sob diferentes lâminas de irrigação e substratos. Revista Brasileira de Ciência do Solo, Viçosa, v.31, n.4, p.713-722, 2007.

MANLY, B. F. J. Métodos estatísticos multivariados: uma introdução. 3.ed. Porto Alegre: Bookman, 2008. 229p.
MARQUES, P. A. A.; BALDOTTO, P. V.; SANTOS, A. C. P.; OLIVEIRA, L. Qualidade de mudas de alface formadas em bandejas de isopor com diferentes números de células. Horticultura Brasileira, Brasília, v.21, n.4, p.649-651, 2003.

MENEZES JÚNIOR, F. O. G.; FERNANDES, $H$. S.; MAUCH, C. R.; SILVA, J. B. Caracterização de diferentes substratos e seu desempenho na produção de mudas de alface em ambiente protegido. Horticultura Brasileira, Brasília, v.18, n.3, p.164-170, 2000.

MESQUITA, E. F.; CHAVES, L. H. H.; FREITAS, B. V.; SILVA, G. A.; SOUSA, M. V. R.; ANDRADE, R. Produção de mudas de mamoeiro em função de substratos contendo esterco bovino e volumes de recipientes. Revista Brasileira de Ciências Agrárias, Recife, v.7, n.1, p.58-65, 2012.

PETTER, F. A.; MARIMON JUNIOR, B. H.; ANDRADE, F. R.; SCHOSSLER, T. R.; GONÇALVES, L. G.; MARIMON, B. S. Biochar como condicionador de substrato para a produção de mudas de alface. Revista Agrarian, Dourados, v.5, n.17, p.243-250, 2012.

R CORE TEAM. R: a language and environment for statistical computing. Vienna: $R$ Foundation for Statistical Computing, 2013.

RAMOS, S. J.; GUILHERME, D. O.; CALDEIRA JUNIOR, C. F.; SAMPAIO, R. A.; COSTA, C. A.; FERNANDES, L. A. Tomato seedling production in substrate containing coconut fiber and mushroom culture waste. Revista Brasileira de Ciências Agrárias, Recife, v.3, n.3, p.237-241, 2008.

RICKLI, H. C.; CAMARGO, L. K. P.; FRANCO, R.; KUNZE, A.; BIASI, L. A. Enraizamento de estacas de patchouli em diferentes substratos. Revista Brasileira de Ciências Agrárias, Recife, v.7, n.3, p.446-450, 2012.

SANTOS, E. L.; PÓLA, J. N.; BARROS, A. S. R.; PRETE, C. E. C. Qualidade fisiológica e composição química das sementes de soja com variação na cor do tegumento. Revista Brasileira de Sementes, Londrina, v.29, n.1, p.20-26, 2007.

SCHMITZ, J. A. K.; SOUZA, P. V. D.; KÄMPF, A. N. Propriedades químicas e físicas de substratos de origem mineral e orgânica para o cultivo de mudas em recipientes. Ciência Rural, Santa Maria, v.32, n.6, p.937-944, 2002.

SILVA, R. F.; SAIDELLES, F. L. F.; KEMERICH, P. D. C.; STEFFEN, R. B.; SWAROWSKY, A.; SILVA, A. S. Crescimento e qualidade de mudas de timbó e dedaleiro cultivadas em solo contaminado por cobre. Revista Brasileira de Engenharia Agrícola e Ambiental, Campina Grande, v.16, n.8, p.881-886, 2012. 
SILVEIRA, E. B.; RODRIGUES, V. J. L. B.; GOMES, A. M. A.; MARIANO, R. L. R; MESQUITA, J. C. P. Pó de coco como substrato para produção de mudas de tomateiro. Horticultura Brasileira, Brasília, v.20, n.2, p.211-216, 2002.

TAIZ, L.; ZEIGER, E. Fisiologia vegetal. 5.ed. Porto Alegre: Artemed, 2013. 820p.
TRANI, P. E.; FELTRIN, D. M.; POTT, C. A.; SCHWINGEL, M. Avaliação de substratos para produção de mudas de alface. Horticultura Brasileira, Brasília, v.25, n.2, p.256-260, 2007.

WENDLING, I.; GATTO, A. Substratos, adubação e irrigação na produção de mudas. Viçosa: Aprenda Fácil, 2002. 146p. 